\title{
Remembering Zimbabwe's War of Liberation through Memories of the August 251979 Mushayi Battle, Dambara Area, Gutu
}

\author{
Joshua Chakawa1, Rudolf Nyandoro² \\ ${ }^{1}$ Department of History, Midlands State University, Gweru, Zimbabwe \\ ${ }^{2}$ Catholic University of Zimbabwe, Harare, Zimbabwe \\ Email: chakawaj@staff.msu.ac.zw,rudny123@yahoo.co.uk
}

How to cite this paper: Chakawa, J., \& Nyandoro, R. (2020). Remembering Zimbabwe's War of Liberation through Memories of the August 251979 Mushayi Battle, Dambara Area, Gutu. Advances in Historical Studies, 9, 240-259.

https://doi.org/10.4236/ahs.2020.94020

Received: March 20, 2020

Accepted: December 4, 2020

Published: December 7, 2020

Copyright $\odot 2020$ by author(s) and Scientific Research Publishing Inc. This work is licensed under the Creative Commons Attribution International License (CC BY 4.0).

http://creativecommons.org/licenses/by/4.0/

(c) (i) Open Access

\begin{abstract}
In rural areas, the liberation war is often remembered through specific battles which afflicted permanent scars on communities. This is the case with the Mushayi battle of 25 August 1979 which involved the Zimbabwe African National Liberation Army (ZANLA) guerrillas and Rhodesian Security Forces (RSFs). The Mushayi homestead is about $63 \mathrm{~km}$ from the small town of Gutu in Masvingo Province. It is located in Dambara area comprising small scale commercial farms (formerly Native/African Purchase Areas). The suffering of affected people as a result of the said battle is central to understanding postwar healing, reconciliation and integration at local level because memory is key in making sense of the world people live in. Grassroots perceptions are important because the sense of sameness over time is sustained by remembering. Political status in Zimbabwe today, 41 years after the armed struggle is hinged on liberation war credentials. The importance of the paper lies in locating demands for compensation and restitution by some victims of the war not only in Zimbabwe but throughout Africa. It also dispels allegations that African Purchase Area farmers always sided with the minority regime since Rhodesians had originally established them to create a content loyal middle class. Last, the article explores the contribution of Purchase Areas as important places for resting, meeting and recuperating under the cover of vegetation.
\end{abstract}

\section{Keywords}

Guerrilla, Peasants, Pungwe, Rhodesian Operatives

\section{Introduction}

Battles of the liberation struggle in part took place among rural communities 
whose inhabitants generally remained in the same areas long after Zimbabwe's armed struggle which formally ended with the signing of the Lancaster House Agreement in December 1979 (Mpofu, 2020: 37). Respondents in these communities continue to discuss the battles, but, however and often wonder why they suffered given that their contributions have not been recognized through some kind of compensation by the post-liberation government. Being survivors of this battle, we were motivated to undertake the research as part of capturing fading memories of Zimbabwe's war of liberation. The paper is premised on challenges that communities have faced since the end of the liberation struggle. It is our contention that important insights may be drawn from recording and paying attention to what and how communities continue to remember, several decades after the events themselves, so as to contribute towards their ability to heal the scars that are a remaining legacy of the war.

First, we give a broad historical background, then an account of the battle itself. The article provides details of Zimbabwe African National Liberation Army (ZANLA) and Rhodesian Security Forces' earlier engagements, the pungwe attack and the battle's immediate and long term consequences particularly on its victims. [Ellert and Anderson (2020: 207) define a pungwe as an all-night gathering involving a combination of song, dance and politics-a ZANLA tactic. At such meetings, sellouts were castigated or even killed in order to cultivate the spirit of total loyalty and commitment to the struggle]. Participants also gave their own understanding of what they thought should have been done to the dead and victims so as to complete the process of healing. This is largely a grassroots perspective based on a single case study. What is clear is that until today, those suspected of "inviting" RSFs to massacre civilians and guerrillas have not been forgiven by their neighbours as well as authorities in power.

This research uses microhistory in its attempt to understand the battle of Mushayi and its wider effects. According to Szijártó (2002: 212), microhistory's strength lies in the fact that it appeals to its readers by transmiting lived experiences, it stands with both feet on the ground of reality, and with all the lines branching out from the event, person or community in focus, it points towards the general. He even goes on to assert that "the best works of contemporary social history are, after all, fruits of such attempts" (212). Issues that are raised in this research largely have to do with the long term consequences of a battle to a small community. The results are quite applicable to general issues of healing and reconciliation on a wider scale. Microhistory approach is appropriate in this study because it has an appeal and can convey real life experience.

\section{Methodology}

The article is based on personal/individual, group and community interviews conducted between July 2018 and February 2019 in Dambara area, Chiguune and Gutu. Participants were accessed through snowball sampling. All of them were either at the battle site, surrounding farms or nearby Chiguune Tribal Trust Lands (now Communal Areas) on 25 August 2020. One of the main respondents 
was Mrs Mushayi or Mai Lydia, the 3rd wife to the late Mr Mushayi the man who was alleged to have reported guerrillas to Rhodesian Security Forces (RSFs). The general tendency has excluded such people for interviews because they are assumed to open wartime wounds which may be on the verge of healing. Mazarire (2010: 99) has asserted that researchers need to go beyond stereotypes invented during the war which defines collaborators and sellouts. He went on to suggest that it is these factors which have blocked historians from winning confidence and access information from those considered to have been on the wrong side of the war (19). Christiansen (2010: 50) argues that these binaries of inside/outsider, authentic/inauthentic and patriot/sellout deliberately exclude others from gaining legitimacy. It is precisely these problems which the researchers sought to address by including such people with the hope that others like them may also share their experiences of the war. Ultimately, this will imply an inclusion of a multiplicity of voices, some of them antagonistic in order to better our understanding of the war and its results.

Samuel Tarupuwa Chihambakwe as a mujibha who was at the battlesite was another key informant. He was interviewed twice, in July 2018 and February 2019 owing to his vast knowledge of the area as a big theatre of the war of liberation. Samuel was key in enabling access to some interviwees who were generally at first indifferent to speaking with outsiders whose presence they thought would be detrimental to their security. Mrs Govhati was at the next farm when the attack did take place just like Mr Gonhi who was also at his home. Generally, oral interviews represented a key source of information to the history of the area, the organization of the war in the Purchase Areas, Mushayi Battle together with its legacy. The rest of the information was obtained from scrutinizing available secondary sources on the war of liberation.

\section{Theoretical Perspective}

The subaltern theory is used to explain the post colonial position of the rural community in relation to the effects of the war on them. In its original application, it was directed on peasants or proletariats. According to Gramsci as cited by Louia (2012: 4), the subaltern classes refer to any "low rank" person or group of people in a particular society suffering under hegemonic domination of a ruling elite class that denies them the basic rights of participation in the making of local history and culture as active individuals of the same nation. Italian groups which Gramsci had in mind at that time as a prisoner were the Italian workers and peasants who were oppressed and discriminated by the leader of the Fascist Party, Benito Mussolini and his supporters (4). Apparently, peasants were the majority in Italy but did not have the (political) power to speak. Galastri (2018: 46) has gone to point out that it is precisely for lack of unity or organization that subalterns are "on the margins of history" or, in other words, do not take part in the integrality or organic unity of the State in which they are subjugated. Subaltern classes share the same history with hegemonic classes but theirs is not officially accepted. This they know and therefore do not labour being recognized by 
the system above them. Further, subalterns lack access to social and cultural institutions of their state. Such a situation therefore perpetuates their marginal status because their voices remain muted.

Subaltern post-colonial theory responds to the question of subjugation and silencing of the oppressed and marginalised people in post-colonial societies. In this particular study, post-coloniality is equated to post-independence. Thus the theory is principally designed to examine the voice of the subaltern subject. Spivak, a postcolonial scholar, holds the view that subalterns cease to be subalterns when they speak (Benedict, 2015: 206). According to de Sousa (2002: 448), the subaltern theory takes the perspective of the "other" as one who has had no voice because of race, class or gender. It establishes the fact that norms are established by those in power and imposed on the "other". Spivak (1988: 270-313) called them a silenced centre. As such, the Gramscian concept of subalternity applies to those groups in society who are lacking autonomous political power.

The theory has been chosen for a number of reasons. First, despite having been victims of one of Gutu's worst battles, peasants in this area have been marginalized particularly by researchers and Civil Society Organizations. Second, they have not been accorded an opportunity to officially share their wartime experiences. Third, the nature of communication networks including poor state of roads and infrastructure speaks volumes of neglect. As such, giving such people a voice may help in rescuing them out of obscurity but more importantly help in sharing what the war means for its marginalized victims.

\section{Historical Background}

Accounts of the war of liberation with battlefield details have up to date been dominated by former white Rhodesian operatives. Some of them include Stiff (1983), Flower (1987), Nell (2011), Godwin (1996), Godwin \& Hancock (1993) and recently Ellert and Anderson (2020) among others. These writers provided detailed explorations which include diagrams, photographs and sketch maps of battles in which they were involved. Critical issues cover the way guerrillas were spotted, organization of the fighting, evacuating the injured and counting losses and gains and to a lesser extent, humiliation of dead bodies. Unfortunately, not many former guerrillas have been able to author their own experiences. As such ex-guerrillas' own accounts are largely eclipsed by those of RSFs' designed to demonstrate the efficiency of the Rhodesian war machine. Wessels (2015), a former Rhodesian operative, for example, discusses his success in tracking guerrillas, fighting as a shock trooper, leading camp attacks, long range reconnaissance, urban operator, sniper, saboteur and seek-and-strike operator. The motive was to emphasise the efficiency of the Rhodesian soldiers while at the same time denigrating guerrillas as poorly trained and organized. One of the reasons driving this "British grounded" genre since Malaya was that it had an audience-a market expecting a particular viewpoint and prepared to buy/pay for books beyond their propaganda value. Consequently, not much from Rhodesian written accounts appeared on the suffering of civilian victims during and after 
the war of liberation which is remembered normally through battles.

In more or less the same way, academics and former nationalist combatants have written on the war and covered some battles. Prominent amomg them include Bhebe (1999), Nkomo (2001), Martin and Johnson (1981), Chung (2007), Kriger (1992), Mazarire (2010), Mujere et al. (2017), Nhongo-Simbanegavi (2003) and so on. The last for example discusses sexual assaults that were meted on ZANLA female guerrillas by their male counterparts especially in Mozambique. The roles and duties of women in the struggle were defined as "mobilising the masses, carrying war materials, caring for children and carrying specific weapons to the front. They were used for preparing food and feeding the comrades". (Nhongo-Simbanegavi, 2003: 82). This attitude was characteristic of gender roles in many rural families. As such concern about women and war is attempted in this work through unbundling the experiences of selected noncombatant women.

Some of the liberation war accounts have relied mainly on elite informants, academics and former guerrillas at the expence of peasants who bore the brunt of the war. The roles of women themselves together with effects of war have remained a grey area. Similarly, accounts by former guerrillas such as Sibanda (2005), Mhanda (2007), Sadomba (2008) and Mpofu (2020) have followed more or less the same pattern as academics. They are largely nationalist accounts with a focus on the reasons for joining the war, attacks at the rear, Rhodesian brutality in general and how they fought as combatants. Little research has been done on the effects of battles on marginalized rural communities although of course wartime experiences have received a fair share of coverage. Recently, Msindo and Nyachega (2019) have focused on the creative ways in which wartime civilians of Honde Valley engaged both government and guerrillas in their attempt to normalize their lives. There is still a need to examine how long after the independence, civilians still feel about the war which many of them were emotionally attached to. The importance of the research by Msindo lies exploring realities of ordinary people. This study examines those beyond the war.

This paper is moving the centre to the grassroots/subalterns through recording battlefield accounts of the often forgotten. This is done in the form of a microhistory covering a battle in which an estimated 50 people died. Such accounts demonstrate that the war was not only fought by those who wielded guns, but also by many whose sacrifices demands recognition. We hasten to point out that we are not suggesting that the Zimbabwean government through the Ministry of Defense and War Veterans should compensate all war victims but only asserting that collections such as this one definitely broaden our understanding of Zimbabwe's (military) history and rural communities and assisting transitional justice processes. While addressing the 1995 International Conference on Zimbabwe's War of Liberation, the late Professor Walter Kamba as cited by Bhebe and Ranger (1995) pointed out that:

"For the sake of Zimbabwe's understanding of itself, we need to raise ques- 
tions about social conflict during and after the war, about gender, about terror and counter-terror, about mobilization and demobilization, about combatants and ex-combatants, and even about dissidents".

This contribution addresses challenges which victims of wartime battles have encountered and the assistance they require from government and nongovernmental organizations.

Mujere, Sagiya, and Fontein (2017) wrote on the massacres at Kamungoma and Hurodzevasikana in Gutu during Zimbababwe's war of liberation. The authors made a brilliant exploration of the memorialization of these events at a local level and at the instigation of community members. They also mentioned other battles fought in Gutu such as Mushayi, Gwiranenzara, Chiwara and Nerupiri. The thinking was that each site should have a shrine in memory of those who were injured or died there. As such if the National Heroes Acre is the climax of the liberation struggle, then there should be memorials even at the lowest level where the war was fought. Mushayi battle sticks out because of the large number of people who died and the silence in academic circles around the battle. This paper begins with a detailed discussion of prior skirmishes in farms around the area of study before dwelling on Mushayi battle.

\section{Prelude to the Battle of Mushayi}

Before the Battle of Mushayi, there were many incidences indicating that Gutu was a bitterly contested front between ZANLA and RSFs. Several white farmers in the area under study remembered as Chomi or Madhodha, Vheri, Chikato or Killian, Mhenduro, Handireki, Brusho, Surry and Fani bore the brunt of the war (Interview with Jopo Mubhunu, 19 January 2019). These farmers became targets of guerrilla violence not necessarily because they were bad neighbours to Africans but because they represented hegemonic system. The murder of white farmers particularly those in remote areas was characteristic of Zimbabwe's liberation war. The Zimbabwe African National Union (ZANU)'s first guerrilla operation inside Rhodesia involved the murder of a white farme P J Oberholtzer in 1964 on the Umtali-Melsetter road by a group under William Ndangana (Ellert and Anderson, 2020: 103). Similarly, cattle were also taken or rustled from white farmers by mujibhas (youngmen who acted as the eyes and ears of guerrillas) with the help and approval of guerrillas. This was a common practice all over rural Rhodesia and was interpreted as a way of taking the war to the white man's doorstep. Prior to the battle of Mushayi, Kokerai homestead was burnt to the ground by Rhodesian Security Forces owing to its link with rustling cattle. Throughout the country, stock theft was a big problem and virtually skyrocketed during the summer months because of seasonal thunderstorms and the washing away of all tracks (Nell, 2011: 342). Although this was dry season, the nature of soils and thick vegetation in the general area of focus could still hide rustled cattle. Sometime in June 1979, cattle belonging to a local white commercial farmer known as Killian (nicknamed Chikato) were stolen by guerrillas and the local 
people in the Nyazvidzi-Dewure area and his house was set on fire. It was clear that white farmers and RSFs would follow-up in order to demonstrate their prowess and if possible, recover the cattle. They were going to reassert their influence in retribution of the loss of their cattle and arson. Kokerai homestead was a common destination for some cattle or beef pilfered from surrounding white commercial farms.

Around midday on 17 June 1979, Rhodesian Security Forces surrounded Kokerai home in pursuit of Killian's stolen cattle. They found only women and children as the men had already fled to hideouts in the morning in fear of Rhodesian reprisals. Stella (January, 2019) added that one white soldier shouted chitunha pano (a corpse here) implying that someone was supposed to die. When her mother enquired about the problem, the white soldier added that handina ukama nekaffir (I have no relationship with a black person). Kaffir was a derogatory term for a black person commonly used during colonial rule. One white soldier started beating her with the butt of his gun. At one time, he hit her on the forehead. She carried the openly visible scar to death 15 years later. It was only at the intervention of Killian himself who was a neighbour that the thorough beating was brought to an end. The other women at home such as Ketty's mother and Tinashe Mubhunu's two wives were also beaten up. Stella was spared after lying that her husband was in the Rhodesian army. The women were then given matches to set their huts and grannaries on fire which they reluctantly did. As the soldiers left, kitchens, sleeping rooms, granaries and every other grassthatched buildings were engulfed in fire.

After the attack, the whole family was rendered homeless and had to sleep in caves. Although cattle had been taken from white-owned farms by guerrillas and mujibhas, it was women who were beaten. The stolen cattle were referred to as cabbages so as to hoodwink enemies. Beef had become commonplace. The beating was caused by the failure to explain satisfactorily the source of beef which was found in some cooking pots. There is no doubt however that Kokerai Farmand its residents were usual receipients of stolen beef. They had also been involved in the stealing of barbed wire and some other property from neighbouring white farms. Collectively, this was still seen as part of the struggle, but on the other hand, whites were convinced that these were terrorist activities.

The extant theory may be used to better grasp the violent response of RSFs supported by local farmers. The theory suggests two seemingly contradictory ways that anticipated state responses to attacks can enter into the strategic calculus of groups. First, attacks that provoke the usually more powerful state to respond with force (Carter, 2016: 134). The idea is that through attacks as these, they may subdue activities which they see as illegal. Farmers were part and parcel of the state which explains why they accompanied the army on its missions. It therefore comes with less surprise why they were also targeted. Farm militias had been created in some farms to protect property, mainly the farmers' cattle and pursue cattles rustlers with the assistance of the army and police. This however was not the case in Gutu farms. 
Another local white farmer, Surry, nicknamed Mapfuranhunzi was in the same month accused by ZANLA and its supporters in the area of helping Rhodesian soldiers to collect bodies of guerrillas killed in battles around Masvingo and hanging them in a net below a flying helicopter. The whole idea was to intimidate guerrilla sympathisers by showing civilians that guerrillas were mortal. As Surry returned from town, he found the gate leading to his house locked. When he came out to investigate he was manhandled by ZANLA guerrillas who had laid ambush and his landrover was immediately set on fire. Guerrillas paraded him through villages and African farms. He was compelled to drink water mixed with cow dung. According to Mrs Mushayi (30 January 2019) everyone had the liberty to beat him up including old men and women. ZANLA guerrillas took him to Tom for a pungwe where those in attendance saw him. As guerrillas learnt that they were being pursued, they had Surry bayoneted, his sexual organs cut off and his body left half buried in the dry riverbed of Nyazvidzi River. Over the next few days, these organs were displayed to many people as evidence of what guerrillas were capable of doing and as indication that the whitemen were not invincible. As a result of the above incident, many white farmers in the Nyazvidzi and Dewure areas, for example Vheri decided to abandon their farms for safety in town. Attacks on the unprotected whites or civilians should also be understood as weapon of the weak addressing imbalances between ZANLA guerrillas and the Rhodesian security apparatus. It was imperative for guerrillas to be seen to be active.

\section{Causes of the Attack}

As is the case with many battles, there were a multiplicity of explanations. One of them included suspicions that Mr Mushayi sold out. He owned the homestead and farm where the massacres took place. According to Samuel, some of his children belonged to Muzorewa's Security Force Auxiliaries (SFAs). Apparently Abel Muzorewa was a moderate leader and at the same time Bishop of the Methodist Church. He formed his auxiliaries in 1978 with maximum support from the minority regime. They operated sided by side with security forces. They were also known as Pfumo ReVanhu or Dzakutsaku. Stella Govhati and Mrs Chando (2019) also pointed out that Mushayi had sons in the army but could not be drawn to provide their specific names. It was even suspected that one of his sons had given him a 2-way radio which he used to communicate with security forces. Yemurai Rwodzi also indicated that Mr Mushayi was absent at his home on the last day of the pungwe. From what she thought, he had walked the whole night to Gutu to inform security forces who attacked and killed both guerrillas and civilians the following morning. On the contrary, Mr Mushayi was actually at home when the bombardment started. In fact, he was shot in the back as reiterated by his third wife (Mai Lydia). The same information was corroborated by a former chief mujibha in the area, Tarupuwa (30 January 2019) who alleged that Mr Mushayi was hiding in some bush just behind his orchard when he was almost shot dead and Rhodesian soldiers asked him why he had not taken out his 
family on time. It therefore remains clear that Mr Mushayi was at home during the attack. That has however not absolved him of selling out.

There are a number of factors that need to be highlighted in relation to suspicions that Mr Mushayi sold out. By rural standards, Mr Mushayi was a prosperous by then. According to Mai Lydia, he owned 17 cattle, many goats, sheep and chickens, a reasonably big garden and had sons working in town. That alone was enough to bring about petty jealousies among his neighbours. Other studies however have shown that in Zimbabwe's war of liberation, sometimes owning a bicycle, going to town regularly, having worked for the government at any one time, being rich or receiving regular visits from security forces, taking one's daughter to town (away from guerrillas) or allegedly being a witch could all lead to one being called a sellout (Chakawa, 2013: 20-33). It was natural that sellouts could be accused of bringing Rhodesian Security Forces to attack guerrillas and villagers. Prosperous peasants were more at risk of being accused of siding with the Rhodesian army.

What is apparent is that on the morning of the day in question, Mr Mushayi was also shot in the back although he survived and was hospitalised. The motivation of selling out raises further questions given that he was a big loser at the end. He lost 5 of his children during the course of the battle. There is no way $\mathrm{Mr}$ Mushayi could have extracted all his 3 wives and children before the commencement of the attack without being suspected by mujibhas, chimbwidos (unmarried female assistants to guerrillas) and other villagers at his home. The norm during the liberation struggle was to associate any enemy attack with the works of sellouts. When communities were attacked by Rhodeian Security Forces, they often looked for possible sellouts from amongst themselves. While the hand of a sellout/informer may not be ruled out completely, guerrillas also relaxed their security measures thus allowing RSFs to take them by surprise. They did not take adequate precautions to secure their base. Mrs Mushayi indicated that when she was being taken to hospital in a Rhodesian military truck, security forces told her that they had actually come close to the homestead the night before. The two soldiers claimed that they overheard talk about more guerrillas coming the following day. Therefore, they decided to postpone the attack by a day. That relaxation was caused by the fact that these farms were taken as places for resting and recuperating because they were thickly forested and therefore concealed. Despite being covered in terms of vegetation, Mushayi's homestead was also less than a kilometer from the road to Buhera. No safety measures had been taken and no Rhodesian military vehicle hit a landmine. The sense of relaxing security measures is common in many theatres of the war and results in guerrillas being taken out by surprise.

\section{The Battle of Mushayi}

Dambara was one of the guerrilla bases in liberated zone of Gutu. Mushayi homestead was popular with ZANLA given that it was surrounded by rocky and thicketed hills which enabled guerrillas to at least identify their attackers from a 
distance and more importantly to conceal themselves. The attack at Mushayi pungwe cannot be separated from the Rhodesians' attempt to demonstrate their invincibility by destroying guerrilla bases. By end of August 1979, preparations for the Lancaster House talks were at an advanced stage. The intention was to show off Rhodesian military strength and by extension, their unpreparedness to accept negotiations which would compromise them. They were bent on proving that the war had not reached a stalemate by inflicting massive damage on guerrillas. It was in this wider historical context that the battle at Mushayi was fought.

Yemurai Rwodzi (July, 2018) remembered that guerrillas who eventually camped at Mushayi were coming from Murambinda. Some of them were based at Sambira hills near Mushayi farm. Guerrillas had started frequenting the hills as from 1978. They had been in this area for close to a year. However they were not permanently based there as they could leave for weeks to some unknown destinations. Samuel Tarupuwa (January 2019) who was a chief mujibha, organizer or runner in the area of Dambara in 1979 recalled that prior to the attack, they had had 3 pungwes with ZANLA guerrillas. Although mujibhas did reconnaissance, patrolled and surveyed the whole area in search of enemy soldiers, they were convinced that the area was safe.

The battle of Mushayi is being ascertained from an eye witness accounts. We should however point out that a battle is unlike a soccer match. Everyone will be trying to survive. It is not something which people can sit and watch. As such, the narratives here help to come up with a comprehensive account of the battle using different experiences. Around 8 in the morning of 25 August $1979 \mathrm{Mu}$ shayi homestead was attacked by Fire Force Helicopter gun-ships with ground support designed for maximum casualties. According to Preston (2004: 72), such attacks began with "vertical envelopment" operations, whereby ground troops would call in the helicopter gunships and heli-borne infantry to destroy the guerrilla band. Attacks normally took place before or just after sunrise so that guerrillas could be pursued in broad daylight. Attacking during the day was a means deployed by Rhodesians to maximise the kill rate. This could be achieved with support from the air, an impossibility at night.

Most guerrillas were relaxing in the hills overlooking Mushayi homestead when the attacks commenced. Ground forces accompanied by airforce initiated the attack against ZANLA forces bases on the hill to the western side by dropping napalm on the area suspected of concealing guerrillas. Smoke and fire were seen from the hill and people began to run away in different directions. Samuel Tarupuwa as a mujibha was there in the hills with a guerrilla called Black Moses and other mujibhas from surrounding farms and communal areas. The running away of Black Moses directly led to the bombing of Mr Mushayi's corrugated main house, the burning of thatched huts and death of his 5 children. When he saw that the house was being bombed, Black Moses is said to have run out through the back door into the orchard where he hid in a mango tree and was shot dead from above (Mrs Mushayi, January, 2019). As Samuel tried to flee the 
area, he was caught by Rhodesian soldiers who had been dropped there to act as stop groups. RSFs held him hostage as they cleared the area of any remaining guerrillas. Taking mujibhas hostage or even killing them was common to security forces in Rhodesia. Nell (2011: 205-228) gives too many examples of such situations. There were important for extraction of intelligence information.

Mrs Mushayi (2019) reiterated that she was shot on both legs while some shrapnels entered her chin. Lydia, her daughter, tried to run away and was shot together with her little brother Wiltshire whom she was carrying on her back. She died just before arriving at the hospital in Mvuma. Mrs Mushayi's other daughter Annatoria was burnt to death in a hut set on fire by security forces searching for guerrillas. Altogether, 5 children from Mushayi died. Charles Mushayi, a grade four primary school child, was badly injured and was hospitalized for 5 months. The indiscriminate killing of children goes on to demonstrate how brutal the war had become. As long as the army had done so in the service of Rhodesia, no charge was laid against them. They were legally insulated well in advance against any killing in war for the good of Rhodesia. The Indemnity and Compensation Act, No. 45 of 1975 protected them. Its main objective was to indemnify members of the security forces in respect, of acts done in good faith for the suppression of terrorism and to enable members of the public to obtain compensation in respect of such acts without waiting for the end of hostilities (Feltoe, 1975 Legalising Illegalities, https://opendocs.ids.ac.uk/opendocs). This meant that they would not hesitate to take hostile measures against perceived enemies of the Smith regime.

\section{The Dead}

Those who died in liberation war battles as civilians or combatants are worth writing about. They are part and parcel of national heritage. Places of massive Rhodesian manslaughter like Chimoio, Nyadzonia and Mkushi have become monuments and the names of those who died there are listed. In 2017, Ian Pringle published a book on the shooting down of the Viscounts in which he mentions all the dead by name (Pringle, 2017). In the same way, those who fell in this battle deserve to be mentioned as part of national heritage and in memorilising the war. A large number of guerrillas and civilians died in this particular battle. From the data obtained during the interviews, the following ZANLA guerrillas were killed in the battle as collected from interviews with Samuel, Yemurai, Mrs Mushayi, Mrs Chando and Mr Gonhi and Job Mubhunu:
1) Black Moses
2) Bhinya
3) Dezzy
4) Nyamayedenga (his body was found 3 days after the battle).
5) Trust
6) Zvichimo
7) Farai
8) Zulu 
9) Douglas

The following civilians from the area of Dambara died in that battle and were buried at their homes:

1) Happison Chapungu

2) Hellen Mhaka

3) Tsitsi Gozhi

4) Francis Mahachi

5) Lydia Mushayi

6) Wiltshire Mushayi

7) Annatoria Mushayi

8) Ndisvitsei Mushayi

9) Winnie Mushayi

10) Christopher Masvaya

11) Gavi

12) Rice

13) Robert Pengezive (mujibha from Buhera)

14) Tobias Mupandawana

15) Misheck Madanhire

There were many more from other areas who died in the battle. Their bodies were taken to Gutu. 25 bodies were buried in a shallow grave by 3 mujibhas, Samuel Tarupuwa, Patrick Nyikadzino and Calisto Nyikadzino who were forced to do so by RSFs. Guerrillas who are remembered to have survived this battle were Take 2, Masinhi and Fadzai Vabereki.

\section{Punishing Collaborators}

With the intensification of Zimbaabwe's war of liberation, communities began to actively participate in the trial and punishment of real or alleged sellouts. Sometimes though not always, they could save individuals from death sentences. Bhebe (1999: 96) highlighted that:

“... the people soon took the initiative to organise themselves in accordance with the party structures. In order to make sure that innocent people were not unnecessarily accused as traitors and then killed by the freedom fighters villagers set up their own branches and 'overall' courts which investigated and tried cases of people brought before them on the charges of being sell-outs... This was because at the beginning so many people were killed by the comrades on flimsy grounds and because they were reported to the comrades as traitors by their enemies".

In this case, Rhodesians punished those who collaborated with guerrillas while ZANLA punished those linked to the regime of the day whether real or perceived. There is no evidence that Mr Mushayi was ever tried by such a court. Rather, he went to live in the small town of Gutu. Being in town was enough evidence to his neghbours and everyone that he was a sellout. From the mentality of the time, only sellouts were protected by the enemy for their own safety and 
that of family members. In fact, it was common in Southern Africa during the liberation war to accuse those from town of being sell-outs. For example, during the war of liberation in Angola, guerrillas and their sympathizers took it as treasonous to go to town or to be heard so planning. According to Brinkman (2003: 311), any attempt to go to town, even to get or to visit relatives and friends could be classified as treason. Staying away for too long when fetching water, receiving visitors, "saying bad things", like talking about town or mentioning salt or another product from town, were all seen as endangering unity and could result in an accusation of treason. In short, the flight of Mushayi to town which was defined as treason among rural dwellers. Returning after the war confirmed him as a sellout despite the absence of concrete evidence. It was a matter of opinion.

Mujibhas captured in the battle were returned for the collection of dead bodies (called zvidhumbu in vernacular) from the battle scene on 26 August 1979. This was a form of punishment which was worsened by being made to bury bodies in a mass grave. According to Benyera (2014: 48), a mass grave is one with more than one body, usually those of civilians, be they identified or unidentified. This definition excludes graves containing the bodies of soldiers or combatants that fell during armed confrontations. Mass graves contain the bodies of victims of gross human rights violations, usually extra-judicially, summarily or arbitrarily executed. Thus bodies in a mass grave are usually found dumped in a haphazard manner, a sign of the manner in which they were killed. The reasons for dumping bodies in a mass graves are obvious. Benyera (2014) points out that a plethora of organisations such as terrorist groups, militias and governments to, inter alia, bury (in mass graves) their victims in a bid to hide the evidence of their heinous actions and also prevent the possible individual identification of the victims. Therefore, identity of some people who died at Mushayi remain unknown. They did not matter to Rhodesians in the same manner that they were insignificant to the Zimbabwean government. It was demanded from the $3 \mathrm{mu}$ jibhas that they burn the dead. They refused because this was one of the worst form of punishment and it was clearly opposed to the local Karanga culture in relation to disposing the dead. The dead should be buried in a clearly marked grave which can later be used for ceremonies relating to the dead. As such, they requested security forces to allow them to dig a mass grave. The request was granted and they dug up a mass grave where the 25 human bodies were dumped.

From Gutu, the 3 mujibhas were taken to Joint Operations Committee (JOC) Victoria (now Masvingo) for interrogation. They were heavily tortured. Part of the punishment included being chained together around a burning fire and being struck with empty beer bottles. Constantly, cold water was poured on them. Torture was common during the war because it was one of the worst methods of extracting intelligence information. That information would lead to more killings. The RSFs were devoted to kill rates (number of guerrillas killed in action against securituy forces at each encounter) because that would also increase their individual rewards for success. The Special Branch (popularly known as SB) were Rhodesian experts in interrogations and torture with a view of gathering 
intelligence. After 4 days, the 3 were taken to Mutimurefu Prison and detained as political prisoners for the next 6 months. Food was provided. Of course, their fair treatment should be understood within the context of the then ongoing Lancaster House talks which culminated in February 1980 elections.

A few days after the war, ZANLA guerrillas returned to Dambara. They were angry with the community for allegedly selling them out. As already discussed, there was no comprehensive evidence pointing to the involvement of locals in inviting Rhodesian Security Forces. Further, the clandestine operations of Selous Scouts in bringing the army should not be undermined. Guerrillas called for a meeting of all men and women to Chihambakwe farm which is approximately 5 $\mathrm{km}$ in an easterly direction from Mushayi Farm. This time they had been cautious enough to avoid meeting close to the road. They wanted to know who had "sold them out". As such both men and women were thoroughly beaten with huge sticks and gun butts on that evening. It was a heavy downpour of rain which stopped guerrillas from continuing with the beating. Some of those who were beaten were Mr Rwodzi, Chiriga, Mahachi, Godfrey Kokerai among others. Both men and women were beaten thoroughly using big sticks (Mrs Chando, January 2019). Women such as Mrs Mahachi and the two wives of Mushayi are some of the people beaten for allegedly failing to report that Mr Mushayi was a sellout. Only Mrs Kokerai was spared of the beating because she was still recuperating from the wounds inflicted on her by a previous beating from Rhodesian soldiers.

It is important to understand use of violence by guerrilla insurgents within the general context of the war. As Marighella (2002: 7), the Brazilian leader who authored the Mini manual of the Urban Guerrilla indicated, "Action creates the vanguard." Individuals will fear denouncing guerrillas because of nasty consequences. Violence reduces confidence in government administrative and police structures by demonstrating that the government cannot fulfill its most essential task of protecting citizens. Violence is used as tool for intimidation. Violence was used as a warning sign that if communities continue to sell out, more disaster would follow them. Those who were suspected of selling out lost their human nature. Therefore, punishing them for misdeeds was justifiable. In a poem about the guerrilla war, Freedom Nyamubaya (1997: 279) tells us that a ZANLA interrogation slogan was: "The truth comes from being beaten".

As a wider punishment as well as deterrent and a directive by ZANLA guerrillas, locals looted Mushayi homestead. What the family lost was not replaced because taking belongings from a sell-out was deemed justifiable within the spirit of the revolutionary war. Normally sellouts are taken as heartless hence justifying inhuman acts against them. Everyone in the community was furious with Mr Mushayi for allegedly selling out (Mrs Mushayi, January, 2019). Window frames, chairs, blankets and doors had already been taken away from his 5 roomed house. What remained were corrugated sheets. He was not quite forgiven by locals and neighbours who throughout his life continued to point at him as a sellout. 


\section{Wounds of the War}

After recuperating from hospital, Mrs Mushayi went to Salisbury (now Harare) to take care of her son who had been shot in the head on this battle. Only after many months was the boy once more able to talk and later on to walk. Mrs $\mathrm{Mu}$ shayi's brother discouraged her from returning to the farm for fear of victimization until after the war. She took that advice. The consequences of the war caused emotions and trauma to the victims which persist to the present day. For Mrs Mushayi, the wounds of that battle continue to haunt her. To start with, she was not allowed to witness the burial of her 3 children who died in that battle which represents psychological torture. She argued that this could have gone a long way in subduing her anger. She was only shown the graves after the attainment of independence when she finally returned. That return meant coming to a completely impoverished home which had been looted of everything. It implied having to work the land without cattle besides being looked at scornfully by the community. She already had six children at the time of attack. She bore 3 more children after the war despite suffering permanent injuries induced by the attack.

Being seemingly ignored and somehow abandoned by those in power after the war is one of the problems which have continued to worry her. She remembered that only once was she visited by a journalist who wanted to cover her experiences in the war. Our visit was the second she had received in 40 years to discuss the historic battle. As she narrated, shrapnels from the battle remain lodged in her body. When she went to hospital on the day of attack, she was told that these would later come out on their own but this has not happened. She said that sometimes this gives her unbearable pain. Her son who survived that battle is taking the responsibility of her medical requirements. From our analysis, what she thought could make her live in peace does not seem expensive. She wants the dilapidated house which was damaged by the war to be repaired, getting medical attention and tombstones for her 3 children who died. This is not restitution but justice to victims of war.

Those who suffered after the war expected some recognition for their contribution during the war of liberation. Samuel decried that mujibhas in communal areas of Buhera were able to enter Dzapasi Assembly Point during the ceasefire. Today, they are in the class of war veterans and have thus ceased to be subalterns. Worse, general lack of information continued to elude those in small scale commercial farms (SSCF) such as Dambara. While their colleagues got compensation for being war collaborators, for mujibhas in Dambara, the compensation is yet to come. Samuel claimed to have tried several times since the early 1990s to take his papers and credentials to Gutu but this has yielded nothing. Roles which they played during the war were not trivial but rather central to the war effort. These included reconnaissance, accompanying guerrillas, carrying materials as couriers, collecting food and blankets, caching ammunition and so on. Some of the duties included punishing sellouts and where need arose, executing 
them. The 2 mujibhas Calisto and Patrick, detained with Samuel were Calisto and Patrick have since been compensated. This is despite that they were junior to him. Samuel indicated that all he wants is money to enable him to live a decent life.

Unlike mujibhas, guerrilla survivors of the battle were held with high esteem after the war. Generally they were not treated as bad because they can openly speak their minds and demand compensation. Not only did they sometimes return to their battle areas, but they also continued to identify with ruling Zimbabwe African National Union Patriotic Front (ZANU-PF) and proceeded to campaign for the party in critical elections. Two guerrillas, Masinhi and Take 2, returned to the area after the war. Take 2 campaigned for ZANU-PF in the elections of 2000 and 2002. He was key in reminding villagers about resilience, consistence and patriotism born out of suffering during the liberation war. While addressing a campaign rally at Chiguune, he explained how he had survived the Mushayi by hiding naked in a cave. As he spoke, mujibhas he had operated with were just faces in the crowd and that is what being a subaltern entails. They did not get the chance to get nearer him let alone greet him. This is the state of helplessness and powerlessness that mujibhas who participated in this war due to many circumstances find themselves in. It also suggests how Zimbabwean nationalism has been reduced to a search for war credentials.

Mrs Mushayi, Samuel Tarupuwa and Yemurai Rwodzi who suffered directly as a result of the battle of Mushayi did not receive any compensation. Similarly, the Mubhunu and Gonhi families whose houses and its property were destroyed before Mushayi battle were also not compensated by government. They have however not formerly applied. When asked, Mrs Mushayi thought that it was natural that she should be paid. Failure to apply for compensation remains a problem. Golaab (2015: 35) has ponted out that compensation has an ameliorative effect which is based on claimant justification. Not all victims are however capable of claiming reparation. Some may be incapacitated by facts that impinge on them. For example, complicity may impede application for compensation. This appears to be the case with Mrs Mushayi. Her husband stood accused and as such, she is not in a moral high ground to ask for compensation. Whatever explanations she may have, she remains gagged as a subaltern. Galoob (2015: 36) calls this wrongdoing subsequent to an injustice which undermines claim to a reparation.

The next queston is whether these wrongdoings have a significance justifying reparation. Can we say that the poverty Mrs Mushayi endures has its roots in the war? Is it possible to conclude that because of the war, Yemurai was unable to mary again? Is the poor living standard of Samuel Tarupuwa a result of the liberation war in Gutu? A "yes" answer justifies reparation. Historical distance also compromises demands for compensation. Decades after independence make it difficult to explain clearly how the victim was farring prior to the wrong and would have fared if not for the wrong (Golaab, 2015: 42). The passage of time affects the confidence one can have in articulating and counting loses. Demands 
for reparation thus become weaker and weaker implying that failure to compensate on time creates another wrong which may be the basis of compensation. After effects of the war have enduring health effects on Mrs Mushayi and that is clear. The same is difficult to explain for Yemurai. If injustices are enduring, they deserve reparation, but again this has not been the case for ordinary civilians.

\section{Memorialising the Dead}

While the civilians who died in this encounter remain completely forgotten, this has not been the case with one of the guerrillas, Nyamayedenga, who died in this battle. Three days after the encounter, his body was found in Mushayi Hill by Tinashe Mubhunu who was hunting in the hills overlooking Mushayi homestead. He recognized the dead man as Nyamayedenga. Locals buried his body in that hill as it was against local Karanga culture to leave the body decomposing in the open. After independence, his remains were exhumed and taken for reburial at Gutu District Heores Acre. That on its on is indicative of government preference towards combatants. Today, Nyamayedenga is interred at a place which can be accessed by everyone with ease while the rest of the civilian population which died at the scene remain forgotten, either in the mass grave or in some unmarked graves at their homesteads, some of which have since been abandoned. A plethora of Acts has been put in place by the Zimbabwean government to cushion war veterans, war collaborators, former political detainees and restrictees. Roughly these include War Victims Compensation Act Acts 22/1980, 31/1983 (s. 25), 33/1984 (s. 8), 24/1987 (s. 15), 13/1988, 18/1989 (s.30), 20/1994, 12/1997, 6/2000, 22/2001; S.Is. 241/1982 (s. 7), 174/1984. However, just letting them speak is not only theraupetic but is historically significant in the sense that it helps in rescuing forgotten archives.

Unlike Hurodzavasikana in Gutu District, no representation has been made to erect some structure in memory of those who died in the battle. A tally from this research put them to almost 50 . Nine guerrillas were confirmed to have died. Fifteen civilians were buried locally while abour twenty-five were buried in a mass grave. It remains unknown if Rhodesian Security Forces died and if so, their number is not known. There is no living former guerrilla from this area to put pressure on the relevant Ministry for proper memorialization. What compounds the situation is that there have been no attempts by people in the community to put up some structure in recognition of those who died in the battle. Noone seems to mind partly because, the general community where the battle took place has not been troubled by spirits of those who died. Furthermore, the only surviving guerrilla in the area, Jonathan, died in the 1990s. Still, he had not fought in the area and was not interested in pushing the memorialization agenda. No strange events have been recorded. The area has generally remained quiet and unrecognized by political figures from the area after the war. As such, there is no compelling reason to construct a structure in memory of those who were 
killed, maimed or injured.

Those who were buried in Gutu in a mass grave remain nameless. There was no effort to positively identify them. No prayer, ceremony or some formal proceedings was associated with the burial of these victims. Only after the reburial of Nyamayedenga was some concrete slab put on the mass grave. Still, it was not clearly marked as a grave and known to a few who are privy to the information such as Samuel. Otherwise, the rest of passersby have no idea what the concrete slab is all about. District heroes acres have been similarly ignored only being cleared towards Heroes Day in August. At Mushayi, there are also no concrete markings for the graves of the five who died in the battle. In short, those who died in the battle except Nyamayedenga remain forgotten except maybe by their immediate family members provided they are still living. By extension, the dead have no share of the victory cake.

\section{Conclusion}

The paper has located Gutu area of Dambara within the whole structure of Zimbabwe's armed struggle from the perspective of memory and trauma of subalterns. It has discussed the major events which include the destruction of Kokerai homestead following the theft of cattle in a neighbouring farm, the murder of a white farmer called Surry and above all, the battle of Mushayi. Eye witness accounts of the battle have been provided. Immediate consequences were mainly the death of almost fifty people in all, punishments to alleged sellouts by guerrillas, detention of mujibhas and the plundering of Mushayi's home. Those who survived the battle continue to live with the scars of the war. Among their expectations are medication, decent houses, money and above all recognition for their sacrifice. They have received no compensation. By examining local battles and their consequences, it is possible to come up with a comprehensive understanding of the liberation struggle as a whole. There is still need to record all other battles one by one as Rhodesian Security Forces have done in relation to their encounters. If that is not done, there is a danger that Rhodesian experiences will creep in one by one and with the passage of time, become official books and documentaries of Zimbabwe's armed struggle.

\section{Conflicts of Interest}

The authors declare no conflicts of interest regarding the publication of this paper.

\section{References}

Benedict, B. (2015). Voice Construction in the Postcolonial Text: Spivakian Subaltern Theory inNigerian Drama. African Research Review, An International Multidisciplinary Journal, 9, Serial No. 39. https://doi.org/10.4314/afrrev.v9i4.16

Benyera, E. (2014). The Contribution of Mass Graves to Healing and Closure: The Case of Chibondo, Mt Darwin, Zimbabwe. International Journal of Humanities and Social Sciences, 4, No. 1. 
Bhebe N. (1999). The ZANU and ZAPU Guerrilla Warfare and the Evangelical Church in Zimbabwe. Gweru: Mambo Press.

Bhebe, N., \& Ranger, T. (1995). Soldiers in Zimbabwe's War of Liberation. Harare: University of Zimbabwe Publications.

Brinkman, I. (2003). War, "Witches and Traitors: Cases from the MPLA's Eastern Front in Angola (1966-1975)". Journal of African History, 44, 303-325 https://doi.org/10.1017/S0021853702008368

Carter, D. B. (2016). Provocation and the Strategy of Terrorist and Guerrilla Attacks. International Organization, 70, 133-173. https://doi.org/10.1017/S0020818315000351

Chakawa, J. (2013). Sellouts and the Liberation War in Zimbabwe: The Case Study of Hurungwe District. In V. Z. Nyawo-Shava (Ed.), Themes in Contemporary History of Zimbabwe: Emerging Perspectives in Afrikology. Gweru: Mambo Press.

Christiansen, L. B. (2010). Zimbabwe's Liberation War Recycled in Saunders C, Documenting Liberation Struggles in Southern Africa: Select Papers from the Nordic Africa Documentation Project, Nordic Africa Institute.

Chung, F. (2007). Reliving the Second Chimurenga: Memories from Zimbabwe's Liberation Struggle. Harare: Weaver Press.

de Sousa, S. B. (2002). Toward a New Legal Common Sense (2nd ed.). London: Lexis Nexis Butterworths.

Ellert, H., \& Anderson, D. (2020). A Brutal State of Affairs: The Rise and Fall of Rhodesia. Harare: Weaver Press.

Feltoe, G. (1975). Legalising Illegalities. https://opendocs.ids.ac.uk/opendocs

Flower, K. (1987). Serving Secretly: Rhodesia into Zimbabwe, 1964-1981. London: John Murray.

Galastri, L. (2018). Social Classes and Subaltern groups: Theoratical Distinction and Political Application. Capital and Class, 42, No. 1.

https://doi.org/10.1177/0309816817692122

Galoob, S. M. R. (2015). A Theory of Liberal Reparation. Ph.D. Thesis, Berkeley: Department of Jurisprudence and Social Policy in the Graduate Division of the University of California.

Godwin, P. (1996). Mukiwa: A White Boy in Africa. London: Picardo.

Godwin, P., \& Hancock, A. (1993). Rhodesians Never Die. Harare: Boabab Books. https://doi.org/10.1093/acprof:oso/9780198203650.001.0001

Golaab, S. M. R. (2015). A Theory of Liberal Reparation. Ph.D. Thesis, Berkeley: Department of Jurisprudence and Social Policy in the Graduate Division of the University of California.

Kriger, N. (1992). Zimbabwe’s Guerrilla War: Peasant Voices. Cambridge: Cambridge University Press. https://doi.org/10.1017/CBO9780511895869

Louia, E. H. (2012). Retracing the Concept of Subaltern from Gramsci to Spivak: Historical Developments and New Applications. African Journal of Historical Culture, 14, No. 1.

Marighella, C. (2002). Mini-Manual of the Urban Guerrilla. Montireal: Abraham Guillen Press.

Martin, D., \& Johnson, P. (1981). The Struggle for Zimbabwe: The Chimurenga War. Harare: Zimbabwe Publishing House.

Mazarire, G. (2010). Rescuing Zimbabwe's Other Liberation Archives. In C. Saunders, Documenting Liberation Struggles in Southern Africa: Select Papers from the Nordic 
Africa Documentation Project, Nordic Africa Institute.

Mhanda, W. (2007). Dzino: Memories of a Freedom Fighter. Harare: Weaver Press.

Mpofu, O. M. (2020). On the Shoulders of Struggle: Memoirs of a Political Insider. Harare: Lan Readers.

Msindo, E., \& Nyachega, N. (2019). Zimbabwe's Liberation War and the Everyday in Honde Valley, 1975 to 1979. South African Historical Journal, 71, 70-93. https://doi.org/10.1080/02582473.2019.1583682

Mujere, J., Sagiya, M. E., \& Fontein, J. (2017). Those Who Are Not Known Should Be Known by the Country: Patriotic History and the Politics of Recognition in Southern Zimbabwe. Journal of East African Studies, 11, 86-114. https://doi.org/10.1080/17531055.2017.1290765

Nell, K. (2011). Viscount Down: The Complete Story of the Rhodesian Viscount Disasters as Told by a SAS Operator, Keith Nell.

Nhongo-Simbanegavi, J. (2003). Gender and Nationalism: The Case of ZANLA. In T. Ranger (Ed.), The Historical Dimensions of Democracy and Human Rights in Zimbbwe, Volume Two: Nationalism, Democracy and Human Rights. Harare: University of Zimbabwe Publications.

Nkomo, J. (2001). The Story of My Life, SAPES Trust.

Nyamubaya, F. (1997). The Killing of Pieter Oberholzer in July 1964. History in Africa, 24.

Preston, M. (2004). Stalemate and the Termination of Civil War: Rhodesia Reassessed. Journal of Peace Research, 41, No. 1. https://doi.org/10.1177/0022343304040050

Pringle, I. (2017). Murder in the Zambezi: A History of Air Rhodesia Viscounts Shot down by Russian-Made Missiles, Ian Pringle.

Sadomba, W. Z. (2008). War Veterans in Zimbabwe's Land Occupations: Complexities of a Liberation Movement in an African Post-Colonial Settler Society, Research School for Resource Studies for Development.

Sibanda, E. M. (2005). The Zimbabwe African People's Union 1961-1987: A History of Insurgency in Southern Rhodesia. Trenton: Weaver Press.

Spivak, G. C. (1988). Can the Subaltern Speak? In C. Nelson, \& L. Grossberg (Eds.), Marxism and the Interpretation of Culture. Urbana/Chicago: University of Illinois Press.

Stiff, P. (1983). Selous Scouts: Top Secret War. Alberton: Galago Publishing.

Szijártó, I. (2002). Four Arguments for Microhistory. Rethinking History, 6, 2. https://doi.org/10.1080/13642520210145644

Wessels, H. (2015). A Handful of Hard Men: The SAS and the Battle for Rhodesia. Philadephia and Oxford: Casemate. 